Beyond Philology No. 17/1, 2020

ISSN 1732-1220, eISSN 2451-1498

https://doi.org/10.26881/bp.2020.1.05

\title{
Nynorsk and the L2 self
}

\author{
JENS HAUGAN
}

Received 30.01.2020,

accepted 14.07.2020

\begin{abstract}
As part of an ongoing project (Educational Role of Language), this paper continues the quest (Haugan 2019b) for finding approaches to second language acquisition that might help understand the challenges for Norwegian pupils/students when trying to learn the alternative written language Nynorsk, in order to develop better teaching didactics.

Norway has two official written language varieties: Bokmål (Dano-Norwegian) and Nynorsk (New Norwegian). Normally, all Norwegian students must learn both varieties of the written Norwegian language in school, and at the end of secondary school, they obtain two separate grades in written Norwegian. However, one of the varieties is considered and taught as the main written language, whereas the other variety is the second or alternative written language.

Approximately 85 percent of the pupils in school have the DanoNorwegian variety as their main written language and many of these pupils develop antipathies against the other variety with the result that they do not master it very well at the end of secondary school. In fact, many pupils achieve better results in English than in the alternative variety of their own so-called mother tongue.

In this paper, I will investigate the approach of Dörnyei (2009), i.e. a motivation-oriented theory of second language learning, and adapt it to learning Norwegian Nynorsk as an alternative written language. According to motivation-oriented L2 approaches, the notion of a L2 self or identity is an important part in trying to acquire/learn
\end{abstract}


a second language. I will claim that this part of language learning is crucial in the understanding of the challenges connected with learning Norwegian Nynorsk as an alternative language. Most language learners would be more motivated to acquire a second language than trying to have a second identity connected to a variety of the same language.

Since the content of this paper is a continuation and extension of the previous work in the same research project and network and I consider the general background crucial for the argumentation, certain parts of the presentation are borrowed or adapted from Haugan (2019b).

\title{
Keywords
}

language teaching, language learning, language acquisition, language didactics, language politics, identity, investment, motivation, social power, Nynorsk

\section{Nynorsk i ,ja" języka drugiego}

\begin{abstract}
Abstrakt
Jako część trwającego obecnie projektu (Educational Role of Language 'Edukacyjna Rola Języka'), ten artykuł stanowi kontynuację poszukiwań (Haugan 2019b) sposobów przyswajania drugiego języka, które moga pomóc zrozumieć wyzwania, jakie stoja przed norweskimi uczniami w związku $z$ nauką alternatywnego pisanego języka norweskiego (nynorsk), w celu rozwoju lepszej dydaktyki nauczania.

Norwegia ma dwie oficjalne odmiany języka norweskiego: bokmål (,język książkowy”, duńskonorweski) i nynorsk („nowonorweski”). Zwykle wszyscy uczniowie w Norwegii muszą uczyć się obu odmian pisanego języka norweskiego w szkole, a pod koniec szkoły średniej otrzymuja dwa oddzielne stopnie $z$ języka norweskiego. Jednakże jedna $z$ odmian jest uznawana i nauczana jako główny język pisany, podczas gdy druga odmiana jest drugim lub alternatywnym językiem pisanym.

Około 85 procent uczniów w szkole uczy się odmiany duńskonorweskiej jako głównego języka pisanego, a wielu $z$ tych uczniów
\end{abstract}


rozwija u siebie antypatię do drugiej odmiany, w wyniku czego nie opanowuja oni jej zbyt dobrze pod koniec szkoły średniej. W rzeczywistości, wielu uczniów osiaga lepsze wyniki w języku angielskim niż w drugiej odmianie własnego języka ojczystego.

W tym artykule zbadam podejście Dörnyei (2009), czyli teorię nauki języka obcego zorientowana na motywację, i dostosuję ją do uczenia się odmiany języka norweskiego pisanego nynorsk. Według podejścia do nauki języka obcego zorientowanego na motywację, pojęcie „ja” lub tożsamości drugiego języka stanowi ważną część w opanowaniu drugiego języka. Będę dowodził, że ta część nauki języka obcego jest istotna w zrozumieniu wyzwań zwiąanych $z$ uczeniem się odmiany języka norweskiego nynorsk. Większość osób uczacych się języka byłaby bardziej zmotywowana do uczenia się języka obcego niż podjęcia próby do zdobycia drugiej tożsamości związanej $z$ odmiana tego samego języka.

Jako że treść tego artykułu stanowi kontynuację i rozszerzenie poprzedniego projektu badawczego i uważam, że ogólny kontekst jest istotny dla argumentacji, dlatego niektóre części zostały zapożyczone bądź zaadaptowane $z$ Haugan (2019b).

\section{Słowa kluczowe}

nauczanie języka, nauka języka, przyswajanie języka, dydaktyka językowa, polityka językowa, tożsamość, inwestycja, motywacja, siła społeczna, nynorsk

\section{Introduction}

This paper is part of an ongoing project within the research network Educational Role of Language (ERL research; ERL 1, 2016; ERL 3, 2018; ERL 4, 2019). As a starting point for my research on the role of Nynorsk ("New Norwegian") as an alternative written language in education, I argued that learning Nynorsk can be said to have much in common with second language (L2) acquisition (Haugan 2016; 2017). Pursuing this approach, I then looked at Norton's (2013) L2 theory of motivation and investment and applied it to learning Nynorsk as an 
alternative written language (Haugan 2018a, 2019b). For the fourth international ERL conference at the University of Craiova, Romania in June 2019 (ERL 4, 2019) I decided to follow the approach of Dörnyei (2009). My recent work has also been discussed at three Norwegian conferences on language and didactics (NNMF7 - Morsmålsfaget som fag og forskningsfelt, Trondheim; MONS18 - Møte om norsk språk, Trondheim; and SPINN - Språkforskning Innafor, Hamar).

I have given a general background of the Norwegian language situation in previous papers (Haugan, 2017, 2019b). Since this is an important part of the argument and the understanding of the topic, I will borrow some of my earlier formulations here to give the reader a short overview over the linguistic and didactic challenge in the Norwegian educational system.

Norway has two official written language varieties: Bokmål (Dano-Norwegian) and Nynorsk (New Norwegian) (see e.g. Wardhaugh 2010: chap. 2, Haugan 2017, 2019b). Unless one is exempt from learning (to write) the alternative variety (for instance because of dyslexia or because of another first language), all Norwegian pupils have to learn both varieties of the written Norwegian language at school. At the end of secondary school, the pupils receive two separate grades in written Norwegian. However, one of the varieties is considered and taught as the main written language (hovudmål), whereas the other variety is labelled the second or alternative written language (sidemål) (see Haugan 2017, 2019b).

Approximately 85 percent of the pupils in school have the Dano-Norwegian variety (Bokmål) as their main written language and many of these pupils develop antipathies against the other variety (Nynorsk) with the result that they do not master it very well at the end of secondary school. In fact, many pupils achieve better results in English than in the alternative variety of their own so-called mother tongue.

Teaching and learning Nynorsk as an alternative written variety of Norwegian comes with many challenges (see e.g. 
Haugan 2017, 2019b, and references there). Therefore, teachers and learners need a better understanding of the conditions for teaching and learning the alternative written language. Since the two written varieties of Norwegian are taught within the same school subject (Norwegian), and since they are (officially/politically) considered being written varieties of the same first language ("mother tongue"), teachers and learners might not be aware of the benefits of approaches to second language acquisition that might help them achieve better results.

The topic of the present paper is an extension of Haugan (2019b) where I tried to both understand and explain the challenges for Nynorsk as an alternative written variety of Norwegian from the theoretical approach of among others Norton (2013) and her key terms identity, investment, social power and motivation. In this paper, I will look at Dörnyei's (2009) L2 Motivational Self System with the hypothesis that the notion of the L2 Self (imagined identity in Norton's model) is the crucial key to understanding the challenges of Nynorsk as an alternative written language in the Norwegian educational system.

Most pupils in Norway do not have a concrete "Nynorsk L2 Self" as a reference, and most pupils, I claim, do not even want to develop or relate to a "Nynorsk identity"; hence, motivation is low and there is a lack of desire to invest in learning Nynorsk. While it may be prestigious to learn and speak English with a certain British or American accent, most pupils of Eastern Norway would connect Nynorsk with Western Norwegian dialects and few pupils would want to adopt an alternative Western Norwegian identity.

It must be emphasized that Nynorsk is supposed to be a written language, meaning that there are not necessarily any explicit demands as to how one should pronounce every word in Nynorsk. The ideological background for Nynorsk as a written language is, among other things, that everyone is supposed to be allowed to use his or her individual dialect in speech. However, historically and practically Nynorsk has more in common with Western Norwegian dialects on a lexical 
plan, and public broadcasting usually favours newscasters with Western Norwegian dialects when it comes to reading news in standardized Nynorsk. Therefore, Nynorsk is usually conceived as a form of Western Norwegian by most pupils in Eastern Norway. Another part of the linguistic picture is the fact that there is no official standard way of speaking Norwegian in general, but there is still a widely accepted unofficial standard based on the dialects in and around the capital of Oslo, usually called "standard Eastern Norwegian", which is relatively close to the major written language Bokmål (DanoNorwegian).

From the perspective of the pupils as part of the educational system, it is also important to reflect upon the fact that the curriculum distinguishes between the two written varieties of Norwegian as the main linguistic form (hovudmål) and the alternative linguistic form (sidemål), meaning that teaching in all other subjects than Norwegian is conducted in the main form, which leads to a conception of the alternative form as a less important (or even unnecessary) form. Since approximately $85 \%$ of the pupils have Bokmål as their main form, sidemail (the alternative form) is often synonymous with $\mathrm{Ny}$ norsk, totally ignoring the fact that there are $15 \%$ of the Norwegian pupils that have Nynorsk as their main form and Bokmål as the alternative form or sidemål. From a more typological perspective, Nynorsk shares characteristics of so-called lesser-used languages (see e.g. the discussion in Walton 2015). Examining teaching and learning of Nynorsk from L2 perspectives may, therefore, yield some new insights compared to just looking at Nynorsk and Bokmål as two forms of one language that functions as the first language or "mother tongue" for most pupils in the Norwegian educational system.

\section{Methodological and theoretical foundations}

The present paper is a contribution to the work of the Educational Role of Language (ERL) network that was established in 
2016 on the background of an initiative from the Division of Research on Childhood and School, Department of Education at the University of Gdańsk. I have been a member of the ERL network since 2016 and published several papers about this particular network and research project (Haugan 2017, 2018b, $2019 b)$. The general information about the ERL network has not changed very much, nor has my main research question, i.e. what would be suitable approaches to understanding teaching and learning Nynorsk as an alternative written language in Norway. Therefore, part of the following short presentation of the ERL initiative is borrowed from Haugan (2018b, 2019b).

The Educational Role of Language (ERL) network consists of researchers from many fields, not only pedagogy, language teaching and linguistics, but also psychology, philosophy and other disciplines that may have an interest in the role of language in a broader perspective. The main goal of the ERL network is to bring together academics whose work and interests combine language and educational science. Following the rationale of the "linguistic turn", network members jointly study how language shapes our understanding of the world and people's functioning in it. There are numerous projects with different perspectives on language beliefs, language activity, language experience and/or language matrices of world interpretation. Hence, the network projects fall within the worldview, psychomotor, affective and/or cognitive domain.

At presents, four key areas build the scope of the ERL network:

- Language Beliefs,

- Language Activity,

- Language Affect,

- Language Matrices.

Language Beliefs are meant to represent students' views on listening, speaking, reading, and writing. Language Activity are 
students' actions consisting in listening, speaking, reading, and writing. Language Affect (formerly Language Experience) deals with students' emotions concerning listening, speaking, reading, and writing, and Language Matrices is about students' world image as shaped by listening, speaking, reading, and writing (ERL network research website). In my research on Nynorsk as an alternative written variety of Norwegian, I try to relate to the main goals of the Educational Role of Language network.

As I stated in Haugan (2019b), Educational relates to education, i.e. in the context of the ERL network, a planned and organized municipal or state activity where children, adolescents or possibly adults are supposed to acquire and develop knowledge and skills according to certain curricula (see e.g. Schmidt et al. 2001). A curriculum is normally divided into general goals and concrete goals. General goals are often related to a general educational approach, which may be easier to understand by referring to the German distinction between the terms Bildung (liberal education) and Ausbildung (formal education, schooling) (see e.g. Schaffar and Uljens 2015). Simply put, one might say that the Bildung aspect of education is often associated with general expectations a society may have with regard to general knowledge about certain subjects. Lack of Bildung is often considered a negative personality trait by many members of a modern so-called "knowledge society" (see e.g. Hargreaves 2003, for a discussion on knowledge society). As for the Norwegian society, the recently revised national curriculum (Læreplanverket 2020) expects (as before) all pupils (with certain exceptions) to master both written varieties of Norwegian, Bokmål and Nynorsk, at the end of secondary school, since both varieties are a part of Norwegian society, culture and history. This may be considered the Bildung aspect of primary and secondary school. The general part of the Norwegian national curriculum (Læreplanverket 2020) states that: 
Opplæringen skal sikre at elevene blir trygge språkbrukere, at de utvikler sin språklige identitet, og at de kan bruke språk for å tenke, skape mening, kommunisere og knytte bånd til andre. Språk gir oss tilhørighet og kulturell bevissthet. I Norge er norsk og de samiske språkene sør-, lule- og nordsamisk likeverdige. Norsk omfatter de likestilte skriftspråkene bokmål og nynorsk. Norsk tegnspråk er anerkjent som et fullverdig språk i Norge. Kunnskap om samfunnets språklige mangfold gir alle elever verdifull innsikt i ulike uttrykksformer, ideer og tradisjoner. Alle elever skal få erfare at det å kunne flere språk er en ressurs i skolen og i samfunnet. (From 1.2 Identitet og kulturelt mangfold (Identity and cultural diversity))

'The education shall ensure that pupils become confident language users, that they develop their linguistic identity and that they can use language to think, create meaning, communicate and bond with others. Language gives us belonging and cultural awareness. In Norway, Norwegian and the Sami languages Southern, Lule Sami and Northern Sami equivalent. Norwegian includes the equivalent written languages Bokmål and Nynorsk. Norwegian sign language is recognized as a full language in Norway. The knowledge of society's linguistic diversity gives all pupils valuable insight into different forms of expression, ideas and traditions. All pupils shall get the chance to experience that knowing several languages is a resource in school and in society.'

(My translation and emphasis, aided by Google Translate)

The general part of the curriculum for Norwegian as a school subject (Læreplan i norsk, NOR01-06) has not changed from the previous curriculum (Læreplan i norsk, NOR1-05) and states that:

Norsk er et sentralt fag for kulturforståelse, kommunikasjon, danning og identitetsutvikling. Faget skal gi elevene tilgang til kulturens tekster, sjangre og språklige mangfold og skal bidra til at de utvikler språk for å tenke, kommunisere og lære. Faget norsk skal ruste elevene til å delta i demokratiske prosesser og skal forberede dem på et arbeidsliv som stiller krav om variert kompetanse i lesing, skriving og muntlig kommunikasjon. 
'Norwegian is a central subject for cultural understanding, communication, formation and identity development. The course will give students an access to the culture's texts, genres and linguistic diversity and will help them develop a language for thinking, communicating and learning. The subject Norwegian will equip students to participate in democratic processes and prepare them for a working life that requires varied competence in reading, writing and oral communication.'

(My translation and emphasis, aided by Google Translate)

The general part of the curriculum for Norwegian as a school subject, thus, emphasizes that Norwegian is a central subject for cultural understanding, communication, education (here with the meaning of Bildung) and identity development. In the revised national curriculum (2020), one has chosen to introduce so-called core elements (kjerneelement). In the section for Norwegian as a school subject, one can read under Tekst $i$ kontekst (text in context):

De skal utforske og reflektere over skjønnlitteratur og sakprosa på bokmål og nynorsk, på svensk og dansk, og i oversatte tekster fra samiske og andre språk.

They [the pupils] shall explore and reflect on fiction and nonfiction in Bokmål and Nynorsk, in Swedish and Danish, and in translated texts from Sami and other languages.'

(My translation and emphasis, aided by Google Translate)

Under the core element "text creation", however, Bokmål and Nynorsk are referred to as "main written form" (hovedmål) and "alternative written form" (sidemål):

Elevene skal få oppleve skriveopplæringen som meningsfull. De skal kunne skrive på hovedmål og sidemål i ulike sjangre og for ulike formål, og de skal kunne kombinere skrift med andre uttrykksformer.

The pupils shall experience writing training as meaningful. They are expected to be able to write in their main written language and their alternative written language in different genres and for 
different purposes, and they are expected to be able to combine writing with other forms of expression.'

(My translation and emphasis, aided by Google Translate)

Under "Being able to write", the curriculum states:

Skriving i norsk innebærer å uttrykke seg med en stadig større språklig sikkerhet på både hovedmål og sidemål. Den første skriveopplæringen skal foregå på elevens hovedmål.

'Writing in Norwegian means expressing oneself with an everincreasing linguistic certainty in both the main written language and the alternative written language. The first writing instruction shall be in the pupil's main written language.'

(My translation and emphasis, aided by Google Translate)

When it comes to the Ausbildung (formal schooling) aspect of education, much less effort is put into teaching the alternative written variety, which is Nynorsk for circa $85 \%$ of the pupils. The pupils receive separate grades in written Bokmål and Nynorsk only after tenth grade (lower secondary school) and thirteenth grade (upper secondary school).

From that perspective, one might say that the official educational system in Norway works according to double standards. By operating with official terms like "main language" (hovudmål) and alternative or "side language" (sidemål), the official curriculum seemingly treats the two varieties as having different values. This opens for an interpretation, by both teachers and pupils, that the alternative written language is less important than the main language. For most pupils - and Norwegian citizens in general, this means that Nynorsk is considered less important or even unnecessary and might also lead to explicit expressions of disrespect and hate.

Education is obviously also politics. National curricula are a state matter (they belong under the Ministry of Education and Research and the Directorate for Education and Training, see udir.no). The two written varieties of Norwegian have actually had official and equal status since 1885, and the distribu- 
tion of Bokmål users and Nynorsk users was about to become relatively even before the Second World War. Even though it is not that easy to measure the actual number of those with $\mathrm{Ny}$ norsk as their main written language in the Norwegian society today, it is usually assumed that approximately $12-15 \%$ or ca. 600000 prefer to write Nynorsk (see e.g. Grepstad, 2015). 12$15 \%$ may not seem a lot, but this is still a substantial number of potential voters in a democracy. Another perspective may be that operating with two official written languages in the educational system and in state matters has certainly also a financial aspect. A returning political question (mostly from conservatives) is, therefore, whether it is "worth" keeping two official written languages - with the obvious underlying rhetorical statement that the major form, Bokmål, should be the only official written Norwegian language.

As in Haugan (2019b), I will take a brief look at the second word of the ERL network name: Role. In the context of Nynorsk as an alternative written language in the Norwegian educational system, two questions may arise: what role does education play, and what part does language play? Role as a term may refer to a more or less active choice to have a certain place or status in a given situation (cf. e.g. Cambridge Dictionary). From the perspective of the Norwegian educational system, one might ask what impact the curriculum has on the treatment of the two written varieties of Norwegian. From the perspective of the individual student, then, one might ask about the status of language (either or both of the official written languages) in education. One aspect would be to what degree the state and official politics would play an active part in the language education of the students. Another aspect would be to what degree the individual student would play an active role in his or her own use of language(s). These two aspects meet at certain points in the educational system or in society; for instance, when failing at mastering the alternative written language, i.e. the lesser appreciated "side language", becomes 
a hinder for entering higher education or obtaining jobs where this language is used as the main language.

The word language in the ERL network, on the other hand, may be self-explanatory. However, certain relevant questions arise when trying to relate this to Nynorsk as an alternative written language in the Norwegian educational system. For those pupils who learn Nynorsk as their main written language and, therefore, first (written) language, would it then be their so-called "mother tongue"? What "language" do Norwegians actually speak? In Norway, most people speak local or regional dialects instead of standard (written) language. Therefore, for most people, neither of the written varieties is an exact representation of the actual spoken language. Hence, both Bokmål and Nynorsk are Norwegian - as explicitly stated in official, political documents, and, at the same time, neither of them is (the only) Norwegian language.

As for the educational system, one frequently returning question is whether it would suffice that the students only learn to read the alternative written language instead of having to learn to write it too. Yet another question is the role and the impact of the written language in the pupils' actual learning activities. Now and then, it is claimed by some of those who want to remove the official status of Nynorsk as an equal language, that Nynorsk, being based on the dialects of "simple" people, due to the fact that the "founder" of Nynorsk, Ivar Aasen, more or less only collected words from rural areas outside major cities to form a genuine Norwegian language that was free(er) from Danish and German influence (see e.g. Haugen, 1965), is not equally suitable as a language in learning activities. Bokmål, on the other hand, being based on the Danish language with hundreds of years of development in academia and state affairs, is a much "better" language for critical and academic thinking and writing, some people claim (e.g. Norsk språkforening). There is indeed a crucial difference in the style of Nynorsk and Bokmål, since many of the complex nouns in Bokmål are preferably expressed as verbal construc- 
tions, e.g. instead of "understanding is important" one would usually rather write "it is important to understand".

Another challenge in the Norwegian society and educational system is the total dominance of Bokmål in academic writing (and writing in general), leading to a situation where most students only know certain expressions and terminology in Bokmål, which might be an extra challenge when reading school texts in Nynorsk. From my personal experience with reading student papers, I notice that some students may even have problems dealing with as simple differences as, for instance, the Nynorsk word forstaing (understanding) for the Bokmål version forståelse. In other cases, the difference may be greater, e.g. Nynorsk dugleik (skill) for Bokmål ferdighet. In many cases, especially in higher education, e.g. teacher education, students would have to write an academic essay on a certain subject using the alternative written language, and the students may fail the exam because of poor language skills even though the content of the paper might be acceptable. This, of course, also raises the questions whether it is "good" education to make students elaborate on academic subjects in a language they do not master very well.

From the perspective of my research on Nynorsk as an alternative written language, the title of the ERL network is highly relevant in itself. I decided to borrow the discussion above from Haugan (2019b) since it is still relevant here when one is interested in trying to understand the challenges for teachers and learners within the Norwegian educational system.

In the next section, I will relate my discussion on Nynorsk as an alternative written language to the research areas of the ERL network: Language Beliefs, Language Activity, Language Affect, and Language Matrices. While my previous work (Haugan, 2019b) focussed on motivation for learning Nynorsk as an alternative written language from the perspective of Norton's (2013) theory of motivation and investment, I will here investigate whether Dörnyei's (2009) notion of the L2 Self 
might be a direct key to understanding the challenges for teachers and learners of Nynorsk as an alternative written language.

\section{Discussion}

As stated in Haugan (2019b), the ERL network has established certain premises for its research activities (see the ERL research link):

- what students think OF language, i.e. students' LANGUAGE BELIEFS (students' views on listening, speaking, reading, and writing);

- how students feel ABOUT language, i.e. students' LANGUAGE AFFECT (students' emotions concerning listening, speaking, reading, and writing);

- what students do WITH language, i.e. students' LANGUAGE ACTIVITY (students' actions consisting in listening, speaking, reading, and writing);

- how students perceive THROUGH language, i.e. students' LANGUAGE MATRICES (students' world image as shaped by listening, speaking, reading, and writing).

These perspectives are still relevant in my present approach. When looking at the ERL research premises, I noticed that they form some kind of causality chain (further explained in Haugan 2019b). What we believe will also have an impact on how we actually experience certain things. Usually, we also act in accordance with our beliefs and earlier experiences. In my previous work (Haugan 2019b), I considered the ERL concepts Language Beliefs, Language Experience/Affect and Language Activity a foundation for motivation. In the present approach, they are seen as the basis for identity and a basis for a possible L2 Self (Dörnyei 2009), an alternative language identity as a didactic ideal and goal.

The problem or dilemma of Nynorsk as an alternative written language are the similarities to a second language (L2) and 
therefore the theoretical implications for learning it as a second language, and the similarities to Bokmål and the political conception of Nynorsk as a variety of the same Norwegian (L1) language, which then would be first language acquisition. Where would one place the concept of language identity or language self in this picture?

Identity or self has, among other things, to do with beliefs, cf. the ERL premises above. In Haugan (2019b), I asked how we could possibly investigate a student's language beliefs about Norwegian. To start with, all Norwegian children learn to locate Norway on a world map as "their" country. Furthermore, they learn that the name of the language in Norway is Norwegian, which is substantiated by the fact that there are books, websites or possibly phone apps named "Norsk ordbok", i.e. Norwegian dictionary. These things indicate that there exists a language that is called Norwegian and that this language is tightly connected to the country Norway. Relatively early, then, a Norwegian child would develop a feeling of language identity (Norton 2013, Dörnyei 2009) connected to the term Norwegian.

However, as a pupil and exposed to the national curriculum one soon also learns that there are two official Norwegian languages, Bokmål and Nynorsk. Hence, the belief about one language - a so-called "mother tongue" for citizens of Norway is seriously challenged by the academic experience in school. The written language the majority of children start to learn in school is Bokmål, the name of this variety being a historical compromise from the time when the Danish version of Norwegian was not considered genuine Norwegian (see Haugan 2017). Suddenly, there is a terminology mismatch. There is norsk (Norwegian) as an adjective or as a possible name for the language, but the written language is called Bokmål (literally "book language").

During the first years in school, the children with Bokmål as their main language are usually not exposed to the alternative written language, Nynorsk (New Norwegian), to the same degree. Soon, therefore, most children - and teachers - begin 
to distinguish between Norsk and Nynorsk in everyday speech, Norsk only referring to Bokmål, the most dominant written language and their main written language. This can be understood as a consequence of the relation between the ERL terms Language Beliefs, Language Affect, Language Activity and, subsequently, Language Matrices. The children already believe (know) they speak Norwegian, which is the official name of the language including all dialects and all written varieties and an adjective naming everything that is related to Norway as a noun. The language they learn to write in primary school, thus, should, naturally, be called Norwegian. Furthermore, the alternative variety is called New Norwegian, hence, the name pair Norwegian and New Norwegian. At this point, it is easy to understand from a linguistic point of view that the word Norwegian, which functions as an adjective and direct derivation from the word Norway, is the most natural word, whereas New Norwegian (Nynorsk) states that there is something new and different - and apparently unnecessary, at least from a child's point of view. In primary school, no children know about political history or language history. Their language identity is Norwegian, not "New" Norwegian (cf. Language Affect and Language Matrices).

This is also reflected in the use of Norwegian, i.e. Language Activity. The main written language, Bokmål for the majority of children, is used in all subjects in school, both in teaching, reading and writing. Bokmål is also the written language that is totally dominant outside school in more or less all public and private domains. The only language activity related to $\mathrm{Ny}-$ norsk is usually sporadic listening to texts in Nynorsk read by the teacher in primary school. After some time, there is sporadic reading of texts in Nynorsk. In most cases, the pupils practice writing more frequently in Nynorsk first in lower secondary school. Hence, in an overall perspective, for the majority of Norwegian students there is minimal language activity related to Nynorsk - even though the Norwegian state and the curriculum, seen from a Bildung perspective, expect all stu- 
dents to master both written varieties by the end of upper secondary school.

For the majority of Norwegian children/pupils the beliefs, experiences and activities related to Norwegian as a language are connected to Bokmål, which consequently becomes synonymous with Norwegian as a general term. Bokmål is the written language most pupils believe to be their natural language ("mother tongue"), experience to be used everywhere in the Norwegian society including the educational system, and practice (cf. activity) themselves on an everyday basis. Nynorsk, on the other hand, is more or less non-existent (from the perspective of the pupils) in everyday life - at least this is what many pupils seem to believe, since it is relatively easy to avoid reading texts in Nynorsk outside school. Experience and activities related to Nynorsk, thus, are related to mandatory school activities. Furthermore, more systematic teaching - and grading - in Nynorsk is postponed until the $8^{\text {th }}-10^{\text {th }}$ grade in lower secondary school and is continued in upper secondary school where the pupils get a separate grade in Nynorsk.

Pupils normally do not share the state's official Bildung perspective on the necessity of mastering both written varieties of the Norwegian language. Pupils have their beliefs, experience and activity connected with Norwegian, which by the time they reach lower secondary school, when they are supposed to be officially graded in Nynorsk, is minimal. At the time of lower secondary school, most children also reach puberty, which often correlates with a general reluctance against mandatory tasks and other aspects of the adult world. At this stage in life and in education, many pupils develop a strong antipathy against learning Nynorsk (see e.g. Garrett 2010, on attitudes to language). Unfortunately, many teachers - being a part of the same educational system and society - share the same antipathy against the alternative language (see e.g. Nordal 2004, and Nordhagen 2006). Consequently, the beliefs about Nynorsk (language attitude) and the experience with this language are not necessarily corrected or altered in any way by 
the teachers, i.e. the official educational system. On the contrary, the impression of Nynorsk as a legitimate "hate object" (language affect) may rather be confirmed and even strengthened.

Recurrently, even politicians, especially from the conservative parties, argue against keeping Nynorsk as a second/ alternative written language in the educational system. It may also be mentioned that many Norwegian newspapers do not allow their journalists to use Nynorsk - even though it has had status as an official and equal Norwegian language since 1885. This is yet another experience for the pupils that would strengthen their belief that Nynorsk is not an "important" part of the Norwegian society and it might even disappear in relatively short time. No wonder motivation to learn the alternative language may be very low. Accordingly, most pupils have lower grades or even fail in Nynorsk, which may have an impact on their future professional life. This is yet another experience that would turn the pupils against it and form the pupils' attitude to the alternative language. Seen on this background, it is easy to understand that most students do not find the motivation to invest (Norton 2013) very much in learning Nynorsk.

Large parts of the discussion and argumentation above are identical to the discussion in Haugan (2019b), but kept here as a starting point due to the same general topic, but slightly different approach. So what new insights would we get in $\mathrm{Ny}$ norsk as an alternative written language from the perspective of an alternative language self (L2 self)?

Dörnyei $(2005,2009)$ established a very fruitful L2 Motivational Self System as a holistic approach to second language acquisition. The concept of motivation comes from the field of psychology, so does the concept of the self. While motivation has been a relatively obvious term within the (more pragmatic or technical) traditional field of teaching and learning, it may not have been equally obvious to focus on the self from the perspective of classroom teaching where there are usually many pupils and motivation at best would be related to a col- 
lective classroom self. When second language acquisition became a distinct research field, it became also clearer that there are individual differences in learning (cf. Dörnyei 2005).

Each pupil represents an individual or self. From the perspective of an ERL approach, this self would, among other things, consist of language beliefs, affect, activity and matrices. This can be related to the "the 'doing' sides of personality" (Dörnyei 2009:10, referring to Cantor 1990: 735). In a teaching and learning context, one would be interested in learning potential and development. The self would, then, be status quo while quo vadis would be possible selves or a future self (Dörnyei 2009, referring to Markus and Nurius 1986, Carver et al. 1994). Possible selves is a plural term and concept since there are usually several or many different possibilities to develop for the individual pupil. In an organized teaching and learning context, the link to Vygotsky's zone of proximal development is rather clear. Vygotsky (1978: 86) defines this zone as "the distance between the actual developmental level as determined by independent problem solving and the level of potential development as determined through problem solving under adult guidance or in collaboration with more capable peers".

I will argue that there are several practical and motivational challenges related to the ideal learning situation and the zone of proximal development or the development of possible selves.

One interesting perspective on the concept of possible selves is that they are supposed to represent "the individuals' ideas of what they might become, what they would like to become, and what they are afraid of becoming" (Dörnyei 2009: 11 with reference to Carver et al. 1994, Marcus and Nurius 1986). This can also be related to the perspectives of the Educational Role of Language network, i.e. Language Beliefs, Language Affect, Language Activity and Language Matrices. As a Norwegian pupil, at some point one has to reflect upon personal language identity based on beliefs, experience/affect, activity, and matrices. As a learner, the general, psychological questions in 
this context would be: Who am I? Who might I become in the future?, and Who would I like to become in the future? As a language learner, more concretely the questions could be rephrased to: Who am I as a language user?/What language(s) do I speak? What languages might I be able to learn in the future?, and Who would I like to be as a language user in the future?

The interesting didactic insight one can deduct from the distinction between potential selves and the future self is that potential selves are more directly related to the curriculum since they contain the notion of so-called ought selves (Dörnyei 2009: 12; Markus and Nurius 1986). Naturally, a curriculum consists of external learning goals, i.e. goals determined by someone else than the individual learner. The nature of a curriculum is to describe future selves based on more or less concrete and measurable learning goals pupils ought to/are expected to reach. When it comes to the individual pupil's motivation and subsequent investment in learning activities (Norton 2013), one can only hope (from a teacher's perspective) that some or one of the possible selves is attractive as a desirable future self in one way or another.

Nynorsk as an alternative written language is in most cases first of all solely a school subject and can often even be said to have more in common with foreign language learning than second language learning (Haugan 2017) since it is mainly restricted to teacher-led classroom activities. As mentioned before, Nynorsk as an alternative written language as a school subject is typically characterized by lack of motivation and investment and may even be a hate object (cf. Language Affect). Therefore, as teachers, one would most likely see this from the perspective of the proximal zone of development (Vygotsky 1978). What kind of teaching and guidance would have the potential to help the pupils on their way to an ought Nynorsk self - or possibly even a self-appointed, desirable future self? While the Anglo-American culture through music, television and movies could tempt Norwegian pupils with a huge variety of potential role models or even idols for a future L2 self, the 
selection of Nynorsk role models is rather limited and - from the perspective (cf. Language Affect, Language Matrices) of many pupils with Eastern Norwegian dialects - non-existent. As mentioned before, there is no established standard way of speaking Nynorsk. The ideological background for Nynorsk has (to a large extent) been to use it as a written language while speaking one's individual local dialect. To the degree that there is some kind of consensus around the sound or way of speaking Nynorsk, this has been partly established by the Norwegian state broadcasting (NRK) by using newscasters from certain Western Norwegian areas (cf. language experience, matrices, beliefs), since Nynorsk traditionally and generally by many is conceived as a Western Norwegian variety. There are very few people who speak standardized Nynorsk and the Norwegian state broadcasting is the only institution who is committed by law to use at least $25 \%$ Nynorsk in their productions. Therefore, for most pupils the only genuine oral Nynorsk reference would come from newscasters on state radio or TV channels. Obviously, children and young pupils are not the target group or the most active listeners when it comes to news programmes on TV or radio. Children programmes, on the other hand, are available everywhere and there are several private channels to choose between. Usually, one speaks dialect in these programmes, and, to the degree that there might be some standardization, this would most often be in the direction of Bokmål and Oslo-region dialects.

Returning to the concepts of possible selves and a (desirable) future self, Nynorsk struggles with another challenge. Partly due to national romanticism and the traditional way of teaching Nynorsk, there is usually a rather huge focus on the fact that the basis for Nynorsk as a standardized written language was developed by one man alone, Ivar Aasen - which is, of course, an important historic fact. However, since this work was done in the mid-1800s and there are only very few pictures of Ivar Aasen showing him as a rather old - not very handsome - man at the end of the 1800s, Ivar Aasen is, obvi- 
ously, not able to compete with modern day role models and idols. Understandably, for many pupils the link between Nynorsk as a lesser used (some might argue hardly ever used) language and the two or three pictures of the very old Ivar Aasen in the teaching of Nynorsk as a school subject might even strengthen the opinion or experience of Nynorsk as an outdated and unnecessary alternative language in the modern Norwegian society. Most pupils would not easily imagine an alternative language identity with these components. It could be strong to claim that this would be a future self the pupils would be afraid of becoming, but there is certainly not much desirable about this possible or future self from the perspective of a young learner who already has a Norwegian speaking and writing identity.

Second language acquisition in the approaches of e.g. Dörnyei (2009) and Norton (2013) convincingly shows the importance of possible or future L2 selves or imagined identities as a crucial component of second language acquisition. In the context of Nynorsk as an alternative written language, this has, however, not been discussed very much, and this approach is not a common part of the education of teachers in Norwegian. While the curriculum explicitly states that Norway has two alternative written languages and that both of them have to be taught in school, the challenges and the public debate in many cases see entirely removing Nynorsk from the curriculum or making it a voluntary school subject as the only alternative instead of addressing the reason for these challenges.

One important part of active learning is self-regulation, i.e. consciously adjusting personal goals and behaviour according to learning progress and learning goals. This aspect is incorporated into Dörnyei's (2009) approach as future self-guides, based on the earlier mentioned distinction by Markus and Nurius (1986: 954) between three types of possible selves:

(1) ideal selves that we would very much like to become,

(2) selves that we could become, 
(3) selves that we are afraid of becoming.

Dörnyei (2009: 15) quotes Pizzolato (2006: 58) stating: "Unlike goal theory, possible selves are explicitly related to a long-term developmental goal involving goal setting, volition (via adherence to associated schemas), and goal achievement, but are larger than any one or combination of these constructs". Dörnyei himself adds to this that "possible selves are 'self states' that people experience as reality" (2009: 16). Somewhere in the teaching and learning landscape, the Norwegian teacher would have to try to help the pupils identify a possible future Nynorsk self that would be realistic to achieve - or even better that the pupils would very much like to become.

The practical component of the teaching and learning model would be self-relevant imagery (Dörnyei 2009: 15 referring to Markus 2006, Markus and Nurius 1986, Ruvolo and Markus 1992). Traditionally, Norwegian teachers have struggled finding "good" arguments that might convince or motivate their pupils to invest in learning Norwegian. In lack of a better argument, many teachers refer to the law stating that government employees in administrative positions would have to be able to write both official languages. Linking this to the concept of possible selves and an ideal future self a pupil would "very much like to become", this argument might not feel much self-relevant for most pupils, and the process of selfrelevant imagery would probably stop rather quickly. Very few pupils would probably be able to imagine a position as a government employee writing formal letters as the most desirable possible self. For most pupils, a future scenario like this would most likely rather be of the "selves that we are afraid of becoming" kind. Furthermore, there will be a new Norwegian language law in 2020 where it might be stated that even state employees are allowed to use their preferred language variety in all written communication. Therefore, teachers might want to look for some better motivational arguments than positions as public servants. 
Dörnyei (2009: 16f.) discusses the role of imagination and imagery and its motivational impact. As a teacher, it would obviously be important not to lead the pupils in the direction of imagining possible selves that they are afraid of becoming when trying to motivate them to learn Nynorsk as an alternative (second) Norwegian language. Language cannot simply be taught, language has to be acquired or learned in the sense that all the efforts a teacher may put into developing teaching lessons would have little or no effect if the pupils do not take an active and conscious part in their own learning process. For a teacher, then, it would be important to realize that "imaging one's own actions through the construction of elaborated possible selves achieving the desired goal may thus directly facilitate the translation of goals into intentions and instrumental actions" (Markus and Ruvolo 1989: 213, quoted by Dörnyei 2009: 16). Dörnyei (2009: 17), referring to Markus (2006) and Boyatzis and Akrivou (2006), sees the dream or image of a desired future as the core content of the ideal self. As discussed before, for most pupils that have to learn Nynorsk as an alternative written language in school due to the curriculum and no other external motivation, a Nynorsk self would not represent a dream or image of a desired future. From a theoretical perspective of L2 acquisition, it is obvious that the Norwegian language situation faces some serious challenges in the public school system.

Another interesting component of Dörnyei's (2009) L2 Motivational Self System is the reference to self-discrepancy theory (Higgins 1987, 1996). This is, naturally, closely related to the notion of a future self, i.e. the relation between status quo and quo vadis, as I have called it before. According to selfdiscrepancy theory, the pupils would be "motivated to reach a condition where the self-concept matches their personally relevant self-guides" (Dörnyei 2009: 18). One could say that this is also related to Vygotsky's zone of proximal development. However, since L2 acquisition is highly dependent on motivation and investment, self-discrepancy theory offers an interest- 
ing approach to new didactic thinking in the teaching and learning of Nynorsk as an alternative written language. Dörnyei (2009: 18) states that:

motivation in this sense involves the desire to reduce the discrepancy between one's actual self and the projected behavioural standards of the ideal/ought selves. Thus, future self-guides provide incentive, direction and impetus for action, and sufficient discrepancy between these and the actual self initiates distinctive self-regulatory strategies with the aim to reduce the discrepancy - future self-guides represent points of comparison to be reconciled through behaviour (Hoyle and Sherrill 2006).

Higgins (1986) and Dörnyei (2009: 18) also point out that there is a crucial distinction between ideal selves and ought selves. I find this distinction highly relevant for the understanding of Nynorsk as an alternative written language in the Norwegian school system. Dörnyei (2009: 18) states:

Ideal self-guides have a promotion focus, concerned with hopes, aspirations, advancements, growth and accomplishments; whereas ought self-guides have a prevention focus, regulating the absence or presence of negative outcomes with failing to live up to various responsibilities and obligations.

Since the exposure to Nynorsk as an alternative written language for most pupils is limited to formal classroom teaching and there is a separate grade in Nynorsk after lower and upper secondary school having a potential impact on whether the pupils can attend higher education or not, the pupils' focus is usually on prevention, i.e. their only goal for Nynorsk as an alternative written language is to pass the test/exam and not to actually learn to master the language. There are usually no hopes, aspirations, advancements or growth for an ideal selfrelated to Nynorsk as an alternative written language. For most pupils, the only actual hope and possible accomplishment they would imagine is to simply pass and to not have to 
use it ever again in the future. Public debates on this issue can take quite unpleasant forms in newspapers and online forums.

Again, from a theoretical point of view, Nynorsk as an alternative written language which is part of the Norwegian curriculum may seem to be "doomed" in a formal teaching and learning context. However, Dörnyei (2009) with his L2 Motivation Self System may help Norwegian teachers find new didactic approaches by reflecting on the theoretical basis for L2 acquisition. Dörnyei, for instance, also discusses conditions for the motivational capacity of ideal and ought selves, pointing out that certain conditions can enhance or hinder the motivational impact of the ideal and ought selves, the most important being (2009: 18):

1 availability of an elaborate and vivid future self image;

2 perceived plausibility;

3 harmony between the ideal and ought selves;

4 necessary activation / priming;

5 accompanying procedural strategies;

6 the offsetting impact of a feared self.

As Dörnyei (2009: 18) states, "The primary and obvious prerequisite for the motivational capacity of future self-guides is that they need to exist." Teachers of Nynorsk as an alternative written language should be aware of this. The pupils need help to develop a self-image with "a sufficient degree of elaborateness and vividness". Having an image of a public servant as the only possible future self has proven not to have much motivational power in the lower or upper secondary classroom. The pupils also need to feel that it is actually realistic and possible to reach the goals of the curriculum or even a Nynorsk self. This has an effect on self-esteem, current mood and optimism (Dörnyei 2009 quoting Segal 2006: 91). With low motivation and low investment, the pupils do not make much progress in their acquisition/learning of Nynorsk, which then, 
naturally, results in bad feedback, which again has an impact on the perceived plausibility that it is realistic or possible to learn Nynorsk. If teachers are made aware of this vicious circle, they might want to develop Nynorsk tasks and tests that would focus on positive feelings like control and mastering.

Dörnyei (2009: 20) also points out that "the ought self is closely related to peer group norms and other normative pressures", and the so-called "norm of mediocrity" may be a typical part of young learners' ought self. Even so the individual pupil may have a certain interest in learning Nynorsk, there is this over hundred year long debate on Nynorsk as an alternative written language, where a common peer norm would be to hate Nynorsk and to put minimal effort in mastering it. It is normally not expected that pupils receive good grades in Nynorsk not even by many teachers. Dörnyei (2009: 20) states that "Oyserman et al. (2006) found that among school children negative group images are often highly accessible, making social group membership feel like it conflicts with academic selfguides, and in such cases teenagers tend to regulate their behaviours to fit with their peers (Pizzolato 2006)." In general, there are very few pupils in the Eastern part of Norway who would develop an academic future self actively involving $\mathrm{Ny}$ norsk in one way or the other. If the interest in Nynorsk against all odds (but it actually happens) - is on a very high level, a pupil would most likely consider changing the main written language to Nynorsk and the whole picture is changed. Certainly, there are pupils who like to achieve good results in all subjects, hence also in Nynorsk. In this case, it is likely that the future self contains a higher degree of general achievement than actual mastering of Nynorsk. However, since most peers do not expect to master Nynorsk at a very high level, expectations are generally lower than compared to other subjects. One could perhaps say that the harmony between the ideal and the ought self is not threatened very much in this context since expectations are low. The whole learning situation would probably gain from classroom discussions and 
reflection, making the pupils aware of this challenge. But as Dörnyei (2009: 20) points out, the self-image must not only be developed, it has to be activated, too. It has to be a part of the working self-concept.

As mentioned before, Nynorsk as an alternative written language in the classroom struggles with being very much limited to classroom contexts only. This means that most pupils are very little exposed to Nynorsk outside school or even outside the particular Nynorsk class they may have once or a few times a week, or even more sporadically depending on the priorities of the teacher. Dörnyei (2009: 20f.), furthermore, states: "In order to translate the aroused motivational potential into action, he/she needs to have a roadmap of tasks and strategies to follow in order to approximate the ideal self." There are definitely teachers who teach Nynorsk as an alternative language rather regularly making it possible "to have a roadmap of tasks and strategies to follow". However, many pupils report that they have had very little organized teaching in Nynorsk through lower or upper secondary school. Naturally, it would have been rather difficult to develop concrete strategies for these pupils. Dörnyei (2009: 21) refers to Oyserman et al. (2006) who argue that "future self-guides are only effective if they are accompanied by a set of specific predeveloped and plausible action plans, which are cued automatically by the image". The challenge for Nynorsk as an alternative written language is, on the one side, that it is difficult to develop a concrete enough future self.

On the other side, there are both practical reasons related to the minimal amount of teaching and exposure, and the more attitude-related issue that Nynorsk in the eyes of many pupils suffers from having low or no status. This makes it difficult to develop concrete action plans.

The last condition Dörnyei chooses to mention is the "offset by feared self" (2009: 21f.). Referring to Oyserman and Markus (1990) he states that "a desired possible self will have maximal motivational effectiveness when it is offset or bal- 
anced by a counteracting feared possible self in the same domain", and "for best effect the negative consequences of not achieving a desired end-state need to be elaborated and be cognitively available to individuals" (Dörnyei 2009: 22). This condition is interesting when applied to Nynorsk as an alternative written language. In most L2 acquisition contexts, there is often a motivation and desire for a future self to "blend in" and be a full member of the L2 community in one way or the other. Not achieving this goal can be related to some kind of fear because of the possible social consequences. For Nynorsk as an alternative written language the social consequences are more or less lacking or minimal. For most pupils the only goal they want to achieve is to pass the obligatory exam in order to finish school and start an education where Nynorsk in most cases is not a mandatory part of the curriculum. If failing the final exam in Nynorsk as an alternative written language is the only feared possible outcome it might be a relevant question - from a didactic point of view - to what degree the teacher should help the pupils elaborate this fear. Many pupils already struggle with understanding why there are two official written Norwegian languages and with accepting the fact that they have to learn Nynorsk at school. Tying the status and the use of Nynorsk for fear of not passing the final test would not exactly benefit the overall political situation. Dörnyei (2009: 22) referring to Oyserman et al. (2006) and Hoylen and Sherrill (2006) states that a balanced combination of pairs of countervailing selves would be most effective, i.e. a combination of both an approach and avoidance of tendencies is expected to be greater motivational factor than the hoped-for or feared self alone. The great challenge for Nynorsk as an alternative written language would be to elaborate a desirable hoped-for future self that is not solely related to passing the Nynorsk exam.

Dörnyei (2009) also discusses the concept of integration in L2 acquisition providing many perspectives that would be relevant in a discussion on Nynorsk as an alternative written language. Due to the length of the present paper, there is no 
space for further elaboration at this point. But the discussion should have shown that Dörnyei's L2 Motivational Self System may be fruitful in the development of future political and didactic approaches to Nynorsk as an alternative written language.

\section{Conclusions}

In this paper, I have discussed the contribution of the Educational Role of Language (ERL) approach to studying language and Dörnyei's (2009) L2 Motivational Self System related to trying to understand the challenges that come with teaching and learning Nynorsk (New Norwegian) as an alternative written language. I have shown that the ERL perspectives of Language Beliefs, Language Experience/Affect, Language Activity and Language Matrixes are very useful tools and that the L2 Motivational Self System offers new valuable perspectives for politicians, curriculum developers, teachers - and pupils. Understanding motivation and language acquisition from the perspective of the L2 Motivational Self System would lead to more awareness around the teaching and learning situation and has the potential to help both teachers and pupils to achieve their goals.

\section{References}

Boyatzis, R. E., K. Akrivou (2006). "The ideal self as the driver of intentional change". Journal of Management Development 25/7: 624-642.

Cambridge Dictionary. Available at <https://dictionary.cambridge. org/dictionary/>.

Carver, C. C., S. L. Reynolds, M. F. Scheier (1994). "The possible selves of optimists and pessimists". Journal of Research in Personality 28: 133-141.

Darvin, R., B. Norton (2016). "Investment and language learning in the 21 st century". Langage et Société 157/3: 19-38. 
Dörnyei, Z. (2005). The Psychology of the Language Learner: Individual Differences in Second Language Acquisition. Mahwah, NJ: Larence Erlbaum.

Dörnyei, Z. (2009). "The L2 motivational self system”. In: Z. Dörnyei, E. Ushioda (eds.). Motivation, Language Identity and the L2 Self. Bristol: Multilingual Matters, 9-42.

Cantor, N. (1990). "From thought to behaviour: 'Having' and 'doing' in the study of personality and cognition". American Psychologist 45/6: 735-750.

ERL 1 (2016) - First International Pedagogical and Linguistic Conference "Educational Role of Language. Learn to speak, speak to learn", University of Gdansk, Poland 2016, 9-10 June, 2016. Available at <http://www.educationalroleoflanguage.ug.edu.pl/ 1st-conf-programme-0>. Accessed 30.01.2020.

ERL 3 (2018) - Third International Pedagogic and Linguistic ERL Conference - "Educational Role of Language - How do we understand it?" Lithuanian University of Educational Sciences, Vilnius, Lithuania, June 14-15, 2018. Available at <http://educa tionalroleoflanguage.ug.edu.pl/sites/default/files/ERL-III-Vilnius -Conference-programme-FINAL.pdf >. Accessed 30.01.2020.

ERL 4 (2019) - Fourth International Pedagogical and Linguistic Conference "Educational Role of Language. Learn to speak, speak to learn", University of Craiova, Romania 2019, 17-18 June, 2019. Available at <http://educationalroleoflanguage.ug.edu.pl/sites/ default/files/ERL-IV-Craiova-Conference-programme.pdf>. Accessed 30.01.2020.

ERL research. Available at <http://educationalroleoflanguage.ug. edu.pl/erl-research>. Accessed 30.01.2020.

Garrett, P. (2010). Attitudes to Language: Key Topics in Sociolinguistics. Cambridge: Cambridge University Press.

Grepstad, O. (2015). Språkfakta 2015. Ei forteljing om språk i Noreg og verda gjennom 850 tabellar. Ørsta: Nynorsk kultursentrum.

Hargreaves, A. (2003). Teaching in the Knowledge Society: Education in the Age of Insecurity. New York: Teachers College Press.

Haugan, J. (2016). "L1, L2 and the case of Norway's written language diversity. How do Norwegian schoolchildren reflect on the social and cultural linguistic world around them?". Paper presented at ERL 1 - Educational Role of Language, Gdansk, June 2016. 
Haugan, J. (2017). "Language diversity in Norway and the question of L1 and L2". Beyond Philology. An International Journal of Linguistics, Literary Studies and English Language Teaching 14/1: 181-204.

Haugan, J. (2018a). "Norwegian Nynorsk - How to write student papers in a variety of your mother tongue that you actually dislike". Paper presented at ERL 3 - Educational Role of Language, Vilnius, Lithuania, June 2018.

Haugan, J. (2018b). "The importance of formal grammar skills: Reflections on Polish students learning Norwegian". Beyond Philology: An International Journal of Linguistics, Literary Studies and English Language Teaching 15/1: 107-132.

Haugan, J. (2019a). "The L2 Self as a challenge in the educational system - seen from the perspective of Norwegian Nynorsk". Paper presented at ERL 4 - Educational Role of Language, Craiova, Romania, June 2019.

Haugan, J. (2019b). "When the first languages feels like a second language: Challenges for learners of Norwegian Nynorsk". Beyond Philology 16/1: 141-164.

Haugen, E. (1965). "Construction and reconstruction in language planning: Ivar Aasen's grammar". Word 21/2: 188-207.

Heller, M. (1987). "The role of language in the formation of ethnic identity". In: J. Phinney, M. Rotheram, (eds.). Children's Ethnic Socialization. Newbury Park, CA: Sage, 180-200.

Higgins, E. T. (1987). "Self-discrepancy: A theory relating self and affect”. Psychological Review 94: 319-340.

Higgins, E. T. (1996). "The 'self-digest': Self-knowledge serving selfregulatory functions". Journal of Personality and Social Psychology $71 / 6: 1062-1083$.

Higgins, E. T. (1998). "Promotion and prevention: Regulatory focus as a motivational principle". Advances in Experimental Social Psychology 30: 1-46.

Hoyle, R. H., M. R. Sherrill (2006). "Future orientation in the selfsystem: Possible selves, self-regulation, and behaviour". Journal of Personality 74/6: 1673-1696.

Læreplan i norsk (NOR1-05) ((previous) National curriculum for Norwegian as a school subject, until 2020). Available at <https: //www.udir.no/k106/NOR1-05>. Accessed 30.01.2020. 
Læreplan i norsk (NOR01-06) (National curriculum for Norwegian as a school subject, from 2020). Available at <https://www.udir. no/lk20/nor01-06>. Accessed 30.01.2020.

Læreplanverket (2020) (Norwegian national curriculum), Utdanningsdirektoratet (Udir). Available at <https://www.udir.no/ $1 \mathrm{k} 20 />$. Accessed 30.01.2020.

Markus, H. R., P. Nurius (1986). "Possible selves: Personalized representations of goals". American Psychologist 41: 954-969.

Markus, H. R., A. Ruvolo (1989). "Possible selves: Personalized representations of goals". In: L. A. Pervin (ed.). Goal Concepts in Personality and Social Psychology. Hillsdale, NJ: Lawrence Erlbaum, 211-241.

Markus, H. R. (2006). "Foreword". In: C. Dunkel, J. Kerpelman (eds). Possible Selves: Theory, Research and Applications. New York: Nova Science, xi-xiv.

Nordal, A. S. (2004). Nynorsk $i$ bokmålsland: ei gransking av undervisningspraksis og haldningar til nynorsk som sidemål $i$ ungdomsskulen i Bærum. Arbeidsrapport. Høgskulen i Volda.

Nordhagen, J. (2006). Nynorsk som sidemål $i$ skolen - en undersøkelse av allmennlærerstudenters personlige og yrkesprofesjonelle holdninger. Hovudoppgåve, Universitetet i Oslo. Master's thesis.

Norsk språkforening. Available at <http://norsk.atspace.com/>.

Norton, B. (2013). Identity and Language Learning: Extending the Conversation. 2nd edition. Bristol, Buffalo, Toronto: Multilingual Matters.

Oyserman, D., H. R. Markus (1990). "Possible selves and delinquency". Journal of Personality and Social Psychology 59: 112-125.

Oyserman, D., K. Terry, D. Bybee (2002). "A possible selves intervention to enhance school involvement". Journal of Adolescence 25: 313-326.

Peirce, B. N. (1995). "Social identity, investment, and language learning”. TESOL Quarterly 29/1: 9-31.

Pizzolato, J. E. (2006). "Achieving college student possible selves: Navigating the space between commitment and achievement of long-term identity goals". Cultural Diversity and Ethnic Minority Psychology 12/1: 57-69. 
Ruvolo, A. P., H. R. Markus (1992). "Possible selves and performance: The power of self-relevant imagery". Social Cognition 10/1: 95124.

Schaffar, B., M. Uljens (2015). "Paradoxical tensions between Bildung and Ausbildung in academia". In: E. Westergaard, J. S. Wiewiura (eds.). On the Facilitation of the Academy. Rotterdam: Sense Publishers, 1-15.

Schmidt, W. H., C. C. McKnight, R. T. Houang, H. C. Wang, D. E. Wiley, L. S. Cogan et al. (2001). Why Schools Matter: A CrossNational Comparison of Curriculum and Learning. San Francisco: Jossey-Bass.

Segal, H. G. (2006). "Possible selves, fantasy distortion, and the anticipated life history: Exploring the role of imagination in social cognition". In: C. Dunkel, J. Kerpelman (eds.). Possibles Selves: Theory, Research and Applications. New York: Nova Science, 7996.

Udir.no. The Norwegian Directorate for Education and Training. Available at <https://www.udir.no/in-english/>. Accessed 30.01. 2020.

Vygotsky, L. (1978). Mind in Society: The Development of Higher Psychological Processes. Cambridge, MA: Harvard University Press.

Walton, S. (2015). "Kva er nynorsken?". In: H. Eiksund, J. O. Fretland (eds.). Nye røyster i nynorskforskinga. Oslo: Samlaget, 16-33.

Wardhaugh, R. (2010). An Introduction to Sociolinguistics. Sixth edition. West Sussex: Wiley-Blackwell.

Jens Haugan

ORCID iD: 0000-0001-9708-2038

Inland Norway University of Applied Sciences

Campus Hamar

2318 Hamar

Norway

jens.haugan@inn.no 